\title{
HÁ LUGAR PARA O ENSINO RELIGIOSO NA ESCOLA?
}

\section{Is there a Place to Religious Teaching at School?}

Viviane Cristina Cândido ${ }^{1}$

\section{Resumo}

Em nossa dissertação, estudamos as fontes do discurso sobre o Ensino Religioso. Para este artigo, considerados os limites desta forma de apresentação, escolhemos apresentar as concepções do Grupo do Não e as reflexões decorrentes para o ER. Ao nos decidirmos pelas fontes a serem utilizadas no trabalho original, optamos por aquelas ligadas à formação da opinião pública, em duas vias: os trabalhos publicados no site: www.strbrasil.com.br. e os artigos publicados pelo jomal Folha de São Paulo. Neste artigo, no entanto, traremos apenas a primeira por considerarmos as questões apresentadas, embora relativas ao Estado de São Paulo, relevantes para o fazer pedagógico do ER em todo o país. Apresentamos a Sociedade da Terra Redonda e seu discurso e compreensão do Ensino Religioso, trabalhando um a um, os textos publicados neste site e apontando as concepções implícitas neste discurso. Como embasamento teórico para compreensão dessa fonte, apresentamos uma leitura do pensamento de Fritjof Capra, relativo à relação entre fé e ciência e de Alain Touraine acerca da modernidade. Para a reflexão acerca da educação e da escola, trazemos Luckesi e Anísio Teixeira. O que pretendemos é contribuir com um avanço na reflexão em busca das bases epistemológicas de um ER possível na escola.

Palavras-chave: Ensino religioso; Concepções; Modernidade; Educação; Escola; Epistemologia.

Doutoranda em Ciências da Religião; Mestre em Educação; Especialista em Teologia para o Ensino Religioso; Pedagoga; Filósofa; Assessora e Consultora Pedagógica em escolas, na formação de professores de ER e outras áreas e gestão escolar. Av. Zelina, 363 - ap. 66 - Vila Zelina - São Paulo - SP

E-mail: vivianecandido@uol.com.br 


\section{Abstract}

In our dissertation we studied the sources of the speech about Religious Teaching. In this article, considering the limits of this kind of presentation, we decided to present the conceptions of "GRUPO DO NÃO" and the reflections towards Religious Teaching.When we decide about the sources that will be used at the original dissertation we chose that ones connected to formation of public opinion, in two ways: the texts published on the site www.strbrasil.com.br and the articles published by the newspaper "FOLHA DE SÃO PAULO" .At this article, however, we will bring just the first one for considerate the questions introduced, even so relative to São Paulo, considerable to the pedagogic pratice of Religious Teaching in all country. We presents the Society of Round Earth and their discourse and comprehension of Religious Teaching, working individually the texts published at this site and indicating the conceptions implicit on this discourse. As theoric base to comprehension of this source we present a reading of the thought of Fritjof Capra, relative to the relation between faith and science, and the thought of Alain Touraine about modemity. Reflecting about education and school we use thought of Luckesi and Anísio Teixeira. What we intend is to help improving the reflection in searching the epistemological bases of a Religious Teaching that is possible at school.

Keywords: Religious teaching; Conceptions; Modernity; Education; School; Epistemology.

"Se as pessoas são boas só por temerem o castigo e almejarem uma recompensa, então realmente somos um grupo muito desprezível". Albert Einstein

\section{Introdução}

No Brasil, o ER - Ensino Religioso é garantido pela Constituição de 1988 e pela LDBEN - Lei de Diretrizes e Bases da Educação Nacional n. 9394/ 96, como parte integrante do currículo das escolas de ensino fundamental, o que o caracteriza como uma disciplina, embora de matrícula facultativa.

A discussão acerca da finalidade do ER exige a reflexão das concepções que fundamentam a educação (VIESSER, 1994, p. 35-43).

Em se tratando de cosmovisão, se partimos da cosmovisão de uma comunidade religiosa, iremos supor a fé dos interlocutores, estaremos fazendo catequese. Se, ao contrário, tivermos um ER tipicamente escolar, cuja cosmovisão considere o ateísmo e as práticas de fé, respeitaremos profundamente a fé dos alunos (GRUEN, 1995, p. 81-82). 
No quarto capítulo de seu livro: Tendências sustentadas por concepções filosóficas, Figueiredo aponta como as tendências do ER resultam das concepções da Igreja e do Estado (FIGUEIREDO, 1994, p. 57).

Estas obras colocaram o ponto de partida para nossa dissertação porque apresentam a necessidade de termos clareza das cosmovisões e concepções que alicerçam o fazer educativo em geral e do ER em particular. Propusemos como objeto de estudo apontar e caracterizar o que chamamos de três fontes de discursos sobre o ER, a saber, a CNBB - Conferência Nacional dos Bispos do Brasil, o FONAPER - Fórum Nacional Permanente para o Ensino Religioso e o grupo que intitulamos "Grupo do Não", aqueles que se posicionam contrários à implantação desta disciplina nas escolas públicas, buscando identificar suas respectivas concepções, divergências, convergências e ambigüidades e seu reflexo nos textos legais, contribuindo assim para uma epistemologia do ensino religioso.

\section{A S.T.R. - Sociedade da Terra Redonda - Brasil}

O site www.strbrasil.com.br traz a seguinte citação de Fernão de Magalhães em sua página de abertura:

"A Igreja diz que a Terra é achatada, mas sei que ela éredonda, porque vi a sombra na Lua, e tenho mais fé numa sombra do que na Igreja".

Na seqüência, apresenta a Sociedade da Terra Redonda, organização brasileira, não-governamental, fundada em 04 de maio de 1999, tendo três objetivos: defender os direitos dos Ateístas na sociedade; advogar pela total e completa separação entre religião e governo e divulgar e promover o método científico e o pensamento crítico, as realizações e os avanços da ciência.

As páginas do site, traduzidas para o inglês e o espanhol, reúnem internautas de todas as regiões do Brasil, bem como alguns integrantes de outros países.

Os textos apresentados são retirados da literatura e de pesquisas em nível nacional e internacional bem como textos que já circularam na mídia, considerados condizentes com os princípios da Sociedade.

\section{A Sociedade da Terra Redonda e o Ensino Religioso}

Trabalhamos os textos um a um, focalizando as idéias centrais que apontam as concepções do Grupo. Consideramos os textos em ordem cronológica decrescente de sua publicação. 
Os artigos aqui trabalhados tiveram como contexto a efervescência do período da aprovação da Deliberação 16/2001 que regulamenta o ER para o Estado de São Paulo. À parte, são relevantes porque os questionamentos trazidos pelo Grupo apontam para necessários aprofundamentos em torno desta disciplina em todo o país.

Antônio Carlos Candia, em seu texto de 26/01/2002, assinala que foi a separação entre a gestão da coisa pública e a hierarquia religiosa confessional que "abriu o caminho para o respeito a todas as crenças e a os cidadãos ateus".

Para falar do ER na escola pública, parte do aspecto legal e aponta que a LDBEN - 9394/96 determina a oferta da disciplina de educação religiosa no ensino fundamental com conteúdo definido pelo sistema público de ensino, ao contrário da lei 3459/2000 que estende a obrigatoriedade ao segundo grau e estabelece que a organização dos currículos caberá às autoridades religiosas. Segundo o autor, a citada lei "institui a educação religiosa confessional nas escolas públicas estaduais, contém várias ilegalidades e confunde as fronteiras entre a necessária liberdade religiosa e a aplicação do dinheiro público de um Estado constitucionalmente laico".

Para ele, se cabe ao Estado, em respeito à própria LDBEN, ouvindo o conjunto das comunidades religiosas, definir o conteúdo, preferencialmente de caráter ecumênico, cabe também contratar professores concursados, já que se trata de dinheiro público. $\mathrm{O}$ autor defende que, minimamente, sejam os professores da própria rede a assumirem a disciplina, a fim de evitar que sejam os representantes das Igrejas os responsáveis pelas aulas.

Para justificar sua preocupação em que os professores não podem ser os representantes das Igrejas, em especial refenindo-se à Igreja católica, dá um exemplo: a indicação ou não do uso da camisinha. $\mathrm{O}$ autor aponta para 0 risco de uma postura moral, por parte de um professor, indicado por determinada confissão, condizente com a postura de sua comunidade de fé, porém distante da situação real dos alunos, neste caso, a necessidade do uso para evitar as doenças sexualmente transmissíveis.

Ao final do texto, o autor lembra:

Devemos garantir a ampliação das liberdades, da informação sobre as diversas fés e doutrinas, mas não podemos perder de vista o que as experiências históricas nos ensinaram, e o que muitos líderes religiosos defendem com convicção - impedir de to das as formas, o retrocesso que seria a volta a uma relação promíscua entre o poder público democrático e as hierarquias confessionais.

A relação entre o poder público e as hierarquias confessionais, na visão do autor, é a base do fundamentalismo religioso, do xiitismo e da intolerância. 
Daniel Sottomaior, um dos editores da STR, escreve em 01/09/2001 o texto Ensino religioso nas escolas: Qual Deus? Parte da deliberação do CEE Conselho Estadual de Educação n. 16/2001. Segundo o autor: "Além de instituir o ensino religioso não confessional como disciplina obrigatória nas escolas públicas do ensino fundamental, a medida prevê que se disponibilize, 'às instituições religiosas das mais diversas orientações', horários para o ensino confessional nas escolas".

Aponta que sob o aspecto legal esta deliberação é uma nítida afronta ao princípio constitucional de separação entre Igreja e Estado.

Na visão do autor, ceder instalações e horários para o ensino confessional transfere os recursos e a legitimidade do estado à religião ${ }^{2}$. 0 ensino não-confessional, ministrado por professores da rede estadual, viola a laicidade do Estado e contraria a LDBEN, segundo a qual o ER deve ser oferecido sem ônus para o Estado ${ }^{3}$. Fundamentando-se na Constituição, afirma que: "Quando se promove a religião e seus valores, sejam quais forem, o que se faz na verdade é privilegiar os indivíduos religiosos e suas concepções e discriminar todos os demais".

E ainda:

"Ao favorecer a religião sobre o secularismo, ele (o ER) ainda infringe 0 art. 5..$^{\circ}$ da Constituição, privando os secularistas, em função de suas convicções filosóficas, dos mesmos direitos que os religiosos".

Para o autor, caso o ER seja instituído, a escola pública se transformará num mercado no qual os credos que possuírem mais recursos materiais e humanos terão o que ele chama de "mídia da sua doutrinação", garantida pelo dinheiro do contribuinte.

Outro problema diz respeito à escolha dos representantes autorizados pelos seus respectivos credos. É necessário considerar a existência de disputas internas de poder nas instituições religiosas que possuem hierarquia, bem como a inexistência, em algumas delas, de hierarquia formal, além da impossibilidade de incluir a variedade de crenças e descrenças. $\mathrm{O}$ autor pergunta como será feita e a quem caberá o poder de decisão para escolher o que seria contemplado ou não pelo ER. O risco é então de haver a predominância das mais populares, conhecidas e poderosas, em detrimento das demais, 0 que seria um exercício de preconceito e não de tolerância.

Evidencia que os documentos do CEE - Conselho Estadual de Educação insistem em que as aulas não se dedicariam a nenhum credo especificamente, o que justificaria o fato dos professores para a disciplina serem os

2 A Deliberação 16/2001 propõe que as escolas cedam espaço para as confissões religiosas, para além do ER realizado nos horários normais de aula.

3 O autor se refere à primeira versão da Lei, corrigida posteriormente. 
licenciados em História, Ciências Sociais e Filosofia. No entanto, e é isto que o autor procura mostrar na seqüência do texto, as declarações que se seguiram à publicação do documento legal, a deliberação 16/2001, mostram uma realidade diferente.

A primeira declaração é do secretário-executivo da CNBB, afirmando que se pretende no ER propor "a relação do ser humano com Deus". A pergunta do autor: Que Deus? Lembra que falar de um Deus único e verdadeiro é pregação religiosa, proselitismo monoteísta.

Relativamente ao fato da medida instituir que as entidades civis sejam ouvidas para definir o conteúdo do ensino interconfessional e a LDBEN apontar que o acordo deva ser entre "as diversas entidades religiosas", afirma que se a implantação do ER intencionasse instruir os alunos para tópicos de sociologia e histónia da religião, bastaria ouvir sociólogos e historiadores leigos. No entanto, 0 que se propõe é que estes sejam os profissionais, porém sem interferir no conteúdo, ficando essa atribuição na mão de quem tem interesse em pregar.

Para mostrar a força de pressão dos grupos religiosos em fazer valer seus interesses, o autor destaca um artigo de D. Cláudio Hummes, Cardeal-Arcebispo metropolitano de São Paulo, publicado pelo jomal O Estado de São Paulo no qual aponta o estabelecimento do ER como uma meta alcançada pelo conjunto das denominações religiosas. Para justificá-lo, o Cardeal afirma que $85 \%$ da população brasileira é católica. Sottomaior traz outros dados segundo os quais $49 \%$ das pessoas acham importante freqüentar cultos religiosos e 19\% se consideram religiosos tradicionais. Segundo o autor, sejam quais forem os números, eles não justificam discriminação.

Do discurso do porta-voz do arcebispo de São Paulo, Amaldo Beltrami, cuja fonte não é citada, o autor destaca: "o ensino religioso é importante para dar a noção de Deus, a noção de responsabilidade social, da solidariedade, para que a nossa juventude já tenha um pouco de ética no seu comportamento".

$\mathrm{O}$ autor observa que igualar ética e religião é uma atitude preconceituosa, pois significa afirmar que os não-religiosos são imorais e antiéticos. Segundo ele, associar esses temas às aulas de religião, como se só aí fossem cabíveis, é uma atitude, no mínimo, amogante.

E continua:

"Essa mistura de preconceito e desconhecimento em relação aos importantes sistemas éticos não religiosos é tão grave quanto comum".

Segundo o autor, isto permeia o próprio documento do CEE e as declarações de seu presidente. Não se justifica uma aula de religião para abordar ética e moral, as quais são ramos diretos da filosofia.

Afirma que os valores de ética, respeito e justiça são diferentes de religião para religião e há muita divergência ao detalhar esses preceitos, mesmo dentro do cristianismo. As diferentes denominações não conseguem con- 
cordar entre si nos pontos mais básicos. Quais seriam os critérios para definir quais os valores e que moral seriam apresentados pelo ER?

Na seqüência, evidencia que muitos dos conteúdos ora pensados para o ER estariam colocados em outras disciplinas. Aponta a impossibilidade de tratar da história sem mencionar religião; bem como na pintura, música, literatura, sexualidade humana. Então pergunta se há necessidade de uma matéria específica, se ela não for doutrinária. Sendo assim, não se justificam as novas contratações nem mesmo o aumento da carga horária.

Diante da proposta de um ER que trabalhe as diferentes Tradições Religiosas, o autor levanta ainda a hipótese de escolhermos seis posturas mais freqüentes, hoje em dia, no planeta, sendo elas dos cristãos, dos muçulmanos, das pessoas sem religião; dos hindus, dos budistas e dos ateus. Ficariam de fora o judaísmo, as religiões da Nova Era e temas importantes no Brasil como as vertentes espiritualistas e afro-brasileiras. Ensinar a história, a antropologia, a sociologia, a filosofia e a psicologia dessas religiões é tarefa impossível para o primeiro grau. Além disso, é necessário considerar o fato de que está prevista apenas uma aula semanal; mais ainda, torna-se problemática a capacitação de professores para esses conteúdos, professores esses que têm diante de si alunos com dificuldade com a própria alfabetização.

É interessante destacar o parágrafo com o qual o autor finaliza esta argumentação:

Esse caviar do conhecimento só teria sentido para alunos já plenos de arroz e feijão, caso contrário não passará de uma manobra para vender o caro prato religioso, pago pelo contribuinte, a jovens e crianças que não têm como se defender. Tudo isso mostra que ainda que a intenção dos legisladores seja a de promover um ensino pluralista e democrático, o resultado será bastante diverso. Seria ótimo se a escola pública criasse jovens e profundos conhecedores das complexas questões que envolvem o fenômeno religioso, mas tal objetivo não é atingível, sequer parcialmente. Atos de vontade não mudam esse fato. Na melhor das hipóteses, sobra apenas o retrocesso a um mal disfarçado proselitismo intolerável e ilegal.

Na finalização de seu texto, Sottomaior mostra que também o ER até a quarta série deixa dúvidas quanto à orientação democrática. Para ele, o tema exige maturidade não compatível com os alunos dessas séries, e o fato de dispersar seus conteúdos em conteúdos de outras disciplinas ${ }^{4}$ desrespeita a determinação constitucional de matrícula facultativa.

4 A Deliberação 16/2001 abre a possibilidade para o tratamento do ER como tema transversal nestas séries. 
No último parágrafo, Sottomaior conclui dizendo da complexidade da questão do ER e da impossibilidade de realizá-lo de maneira justa, equilibrada, democrática e não proselitista. Lembra os líderes religiosos Henry Sobel e Ariovaldo Ramos que, segundo ele, reconhecem os erros e contradições da proposta e a condenam.

Outro artigo publicado pela Folha de São Paulo no dia 23/08/2001 foi, no dia seguinte, publicado no site da Sociedade da Terra Redonda. Em ambas as publicações, teve como título O parlamentar que votou contra Deus e é de autoria de Hélio Schwartsman.

O autor inicia sua argumentação dizendo que assim como as igrejas não ensinam física e aritmética em seus cultos, a escola pública não deveria ensinar religião.

Apresenta o parágrafo 1. ${ }^{\circ}$ do artigo 210 da Constituição Federal que estabelece o ER e evidencia o fato de que São Paulo foi o último Estado da União a regulamentar a matéria. A regulamentação só se deu, segundo o autor, devido à pressão de grupos religiosos resultando na lei n. 10.783, a qual está em observância à Constituição e ao artigo 33 da LDBEN.

Para o autor, a grande questão está na definição dos parâmetros curriculares, pois, embora a Secretaria Estadual de Educação pretenda dar um caráter histórico-antropológico à matéria, a intenção do legislador, que elaborou o parágrafo $1 .^{\circ}$ do artigo 210, não teria sido essa, já que prevê o ER para alunos de 1. a ${ }^{a}{ }^{a}$ séries e não no Ensino Médio, onde os grandes teóricos da antropologia poderiam ser trabalhados com algum proveito. Disto decorre, nas palavras do autor que: "De forma autoritária, o Constituinte estava pensando em impor um catecismo a crianças facilmente impressionáveis e que têm poucas chances de se defender de idéias ou doutrinas que lhe sejam apresentadas por alguém com a autoridade de um professor".

A seu ver, sendo assim, quando a secretaria sugere optar por um conteúdo eminentemente laico e por aulas ministradas por docentes com formação em história, ciências sociais ou filosofia tenta evitar o pior.

Cita então, mais uma vez, a pressão de católicos e evangélicos para "aparelhar" as aulas de religião lembrando a declaração de Monsenhor Arnaldo Beltrami ${ }^{5}$.

Contra argumentando o autor afirma não crer que esses valores só possam ser ensinados com recurso à idéia de Deus e considera contraproducente procurar elementos comuns à maioria das religiões quando a meta é ensinar o respeito à diversidade.

Destaca ainda que as autoridades educacionais paulistas pretendem criar aulas específicas de religião apenas nas últimas séries do primeiro grau.

Citada na página anterior. 
Antes disso, as informações seriam diluídas dentro do conteúdo das outras disciplinas, o que feriria o direito do aluno de não assistir às aulas, pois o ER é de matrícula facultativa. Quanto a isso, destaca a dificuldade dos alunos em optarem por não assistirem às aulas de religião lembrando como crianças "são seres particularmente cruéis".

Finalizando o texto, o autor frisa que não tem nada contra a religião, desde que essa seja ensinada e não imposta, pelas igrejas e nas igrejas. Considera ainda uma coerção tolerável, uma mãe levar o filho a uma missa ou culto. Mas quanto ao Estado, o autor é categórico: seu papel na vida espiritual dos cidadãos deve ser o de garantir a liberdade de culto. Nem mais, nem menos.

Considera improvável uma emenda constitucional que retire essa 'barbaridade' da Carta, já que nenhum deputado se arriscaria a ficar conhecido como 'o parlamentar que votou contra Deus'.

O texto de Newton Brito, datado de 11/05/2001, parte da afirmação de que os religiosos de todos os matizes conservadores consideram o ensino dos valores religiosos pelo Estado como solução para deter a onda de violência e a desagregação moral da sociedade brasileira. Para ele, por trás disso está o desejo de transformar a sociedade brasileira num Estado submisso à religião nos moldes do Irã, Afeganistão e outros modelos.

Referindo-se ao paralelismo entre a tradição religiosa das sociedades islâmicas com a religiosidade historicamente cristã da sociedade brasileira, sustenta que há duas semelhanças entre a visão religiosa nas sociedades islâmicas e a visão religiosa dos setores conservadores da sociedade brasileira: a leitura religiosa dos dois grupos é de caráter fundamentalista e ambos têm como prerrogativa a mescla entre o Estado e a religião. Em se tratando da sociedade brasileira, exemplifica apontando que no preâmbulo da Constituição de 1988 afirma-se que ela foi promulgada sob "inspiração de Deus" e em notas aparece a frase "Deus seja louvado".

Para o autor, se os religiosos estivessem realmente preocupados com valores e contrários à violência, estimulariam a obrigatoriedade da disciplina Ética, a qual seria assumida por professores de Sociologia e Filosofia, os quais teriam a necessária competência para trabalhar valores de caráter humanista.

Na seqüência do texto, o autor sugere exemplos de professores de religião da Igreja Universal do Reino de Deus ensinando e transmitindo a carga de preconceitos e de intolerância que estes religiosos carregam e os professores da Igreja Católica falando contra o uso de anticoncepcionais e do homossexualismo como aberração. Ou um aluno espírita sendo bombardeado com a idéia de que suas crenças são frutos de espíritos demoníacos. E tudo isso com dinheiro público, lembra.

Para ele, o objetivo desses grupos é obter a hegemonia ideológica a fim de que as pessoas fiquem bitoladas pela mentalidade religiosa e não se 
conscientizem da necessidade de transformações sociais. A obrigatoriedade do ER corresponde à necessidade desses religiosos de chegarem ao poder e "implementarem sua versão fundamentalista religiosa estatal". O ER é "uma espécie de preparação mental, um sedativo para facilitar esse projeto".

Na finalização do texto, se defende daquilo que os leitores poderiam considerar como o que ele mesmo chama de "exagero de ateu". Lembra que poucos se importaram com o surgimento do nazismo na Alemanha e viam Hitler como um indivíduo exótico, até quando o viram no poder e conclui: Adolf Hitler era católico.

\section{Concepções implícitas}

O Grupo do Não toma esta posição baseado na secularização, no reconhecimento da ciência como única forma de explicar a realidade e na clara concepção do estado laico, ou seja, baseia-se nos pressupostos da modernidade.

Do texto de Antonio Carlos Candia podemos destacar a compreensão de que a separação entre religião e Estado seja a base para o respeito a todas as crenças e aos cidadãos ateus. $O$ Estado laico deve manter as fronteiras entre a liberdade religiosa e a aplicação do dinheiro público, daí a compreensão de que o ER não pode prever a confessionalidade.

Implícita, no texto de Daniel Sottomaior, está a concepção da separação entre Igreja e Estado como um princípio constitucional, não sendo legítimo ao Estado prover recursos humanos e materiais para o ensino confessional. A concepção de que a promoção das religiões e de seus valores, sejam quais forem, privilegia os indivíduos religiosos e discrimina os demais e que os valores éticos são secularizados.

$\mathrm{O}$ autor vê as religiões, sobretudo, o catolicismo, como detentoras de poder. Concebe como sendo impossível a estruturação de um currículo de ER que leve em conta as diferentes religiões, já que iriam predominar as religiões mais populares em detrimento das demais.

Para o autor, não há um Deus único. Ele reconhece a existência de diferentes experiências, nem sempre condizentes com a existência de um Deus.

Destaca-se ainda a concepção secularizada da ética e da moral como ramos da filosofia e, necessariamente, devendo ser compreendidas fora das religiões, pois isto implicaria em um explícito preconceito, o de acreditar que fora das religiões não há ética e nem conduta moral.

Apresenta ainda a concepção do educando de $1 .^{\mathrm{a}}$ a $4 .^{\mathrm{a}}$ série como influenciável. Segundo essa caracterização psicológica, não se pode falar do caráter realmente facultativo da matrícula desta disciplina. 
A concepção de que a educação religiosa cabe às igrejas e não ao Estado laico perpassa todo o artigo de Hélio Schwartsman.

Assume a posição de que não é preciso recorrer à idéia de Deus para ensinar valores e de que a meta é ensinar o respeito à diversidade sendo então contraproducente procurar elementos comuns à maioria das religiões. $\mathrm{O}$ autor reflete também uma concepção secularizada dos valores.

Com relação à matrícula facultativa, entende que as aulas de ER poderiam representar uma coerção exercida entre as próprias crianças. Quanto ao Estado, cabe garantir a liberdade de culto.

$\mathrm{O}$ autor Newton Brito concebe o Estado como instituição obrigatoriamente laica. Reconhece uma relação histórica entre religião e Estado, que constantemente ameaça o Estado laico. Entende as religiões como poder e os religiosos como aqueles que pretendem uma hegemonia ideológica. A religião, conservadora e fundamentalista, é um corpo de doutrinas a impedir os seres humanos de enxergar os seus problemas e buscar reais soluções para eles.

Na visão do autor, a sociedade brasileira possui uma religiosidade historicamente cristã e o ser humano é passivo diante do poder da religião e dos religiosos. $\mathrm{O}$ educando se comporta como mero receptor da transmissão doutrinária.

Neste sentido, o ER seria uma forma de propagar a ideologia religiosa, em nada contribuindo para valores novos e autênticos, até porque, em sua concepção, valores de caráter humanista deveriam ser ensinados a partir do estudo dos pensadores.

\section{Fundamentos}

Para elucidar o posicionamento do Grupo do Não relativo à separação entre a ciência e a fé, trazemos a seguir o pensamento de Fritjof Capra.

Ao iniciar o capítulo intitulado A máquina do mundo newtoniana, diferencia a natureza das ciências medieval e contemporânea utilizando como categoria a relação entre a razão e a fé. A ciência medieval:

Baseava-se na razão e na fé, e sua principal finalidade era compreender o significado das coisas e não exercer a predição e o controle. Os cientistas medievais, investigando os desígnios subjacentes nos vários fenômenos naturais, consideravam do mais alto significado as questões referentes a Deus, à alma humana e à ética (CAPRA, 2003, p. 49).

Nos séculos XVI e XVII esta noção de um universo orgânico, vivo e espiritual foi substituída pela noção do mundo como uma máquina, metáfora dominante do mundo moderno. A revolução científica iniciada por 
Copérnico culmina no momento em que a terra deixa de ser o centro do universo enquanto o homem deixa de ser a figura central da criação de Deus.

Galileu que, segundo a leitura do autor, tem o mérito de combinar a experiência científica com o uso da linguagem matemática, dirigiu a atenção para as propriedades quantificáveis da matéria, o que foi assumido pela ciência moderna e exigiu o ônus da expulsão da experiência do domínio do discurso científico (CAPRA, 2003, p. 51).

Ao tratar da visão cartesiana, é destacado o empenho de Descartes na construção de uma nova filosofia científica, movido pela certeza de que Deus lhe apontava uma missão (CAPRA, 2003, p. 53). Trazemos essa idéia com o objetivo de destacar como a ciência moderna nasce impregnada pelos valores e crenças do período medieval.

$\mathrm{O}$ que queremos afirmar é que, embora a modernidade sinalize 0 total abandono de Deus como referência, nos moldes do período medieval, vale destacar que esse abandono, por assim dizer, se dá aos poucos, haja vista o dado curioso de que Descartes, considerado o pai do pensamento científico moderno, parta, em suas razões pessoais, da concepção de ter uma missão designada por Deus.

Ao explicitar a divisão fundamental entre a mente e a matéria que embasa a concepção cartesiana da natureza, o autor afirma:

Mente e matéria eram criações de Deus, que representava o ponto de referência comum a ambas e era a fonte da ordem natural exata e da luz da razão que habilitava a mente humana a reconhecer essa ordem. Para Descartes a existência de Deus era essencial à sua filosofia científica (...) (CAPRA, 2003, p. 55).

Também em Newton, o autor destaca sua visão de Deus e cita 0 trecho a seguir extraído da obra Óptica de Newton:

Parece-me provável que Deus, no começo, formou a matéria em partículas sólidas, compactas, duras, impenetráveis e móveis, de tais dimensões e configurações, e com outras propriedades tais, e em tais proporções com 0 espaço, que sejam as mais compatíveis com a finalidade para que Ele as formou; e que essas partículas primitivas, sendo sólidas, são incomparavelmente mais duras do que quaisquer corpos porosos compostos por elas; realmente tão duras que nunca se desgastam nem se fragmentam, e não existe nenhuma força comum que seja capaz de dividir o que o próprio Deus unificou na criação original (CAPRA, 2003, p. 61).

Embora estejamos evidenciando a crença religiosa dos cientistas modernos, importa-nos salientar aqui seus avanços em relação à busca do 
Há lugar para o ensino religioso na escola?

conhecimento científico e suas postulações, cada vez mais distanciadas das concepções religiosas.

Na seqüência de seu texto, irá afirmar esse distanciamento de Deus:

Esse quadro de uma perfeita máquina do mundo subentendia um criador externo; um deus monárquico que governaria o mundo a partir do alto, impondo-lhe sua lei divina. Não se pensava que os fenômenos físicos, em si, fossem divinos em qualquer sentido; assim, quando a ciência tornou cada vez mais difícil acreditar em tal deus, o divino desapareceu completamente da visão científica do mundo, deixando em sua esteira o vácuo espiritual que se tomou característico da corrente principal de nossa cultura. A base filosófica dessa secularização da natureza foi a divisão cartesiana entre espírito e matéria (CAPRA, 2003, p. 61).

Afirma ainda que, em conseqüência dessa divisão, o mundo passa a ser um sistema mecânico suscetível de ser descrito objetivamente, sem mencionar o observador humano. É assim que sinaliza, em seu texto, o momento em que a ciência, por assim dizer, se afasta de Deus.

Um empolgante texto a respeito do nascimento da ciência por Loyola, 2004, p. 1, extraído da Internet, começa com uma citação mostrando como a evolução do comércio ajudou a derrubar antigos dogmas:

Depois de mil anos de cultivo, o solo [europeu] voltou a florescer; os bens se multiplicaram, criando excedentes que levaram ao comércio; e o comércio em suas encruzilhadas voltou a construir grandes cidades nas quais os homens podiam cooperar para estimular a cultura e reconstruir a civilização. (...) Aqui e ali, em universidades, mosteiros e retiros escondidos, homens deixaram de disputar e começaram a investigar; (...) À medida que aumentava o conhecimento, diminuía o medo; os homens pensavam menos em adorar o desconhecido, e mais em dominá-lo. Todo espírito vital foi estimulado por uma nova confiança; barreiras foram derrubadas; não havia limites, agora, para o que o homem poderia fazer (DURANT, 1991, p. 117).

Após esta interessante citação, continua o texto:

Havia nascido a ciência. E com ela uma nova maneira de encarar o mundo. (...) Com o avanço da ciência, por mais que os pensadores afirmassem A, se a experiência prática dissesse $B$, não havia como negá-la. (...) Quanto mais a ciência progredia, mais Deus recuava. Se a evolução do mundo natural permitiu o surgimento dos planetas, da vida e do homem por meras leis físicas - as mesmas que governam o nosso mundo do dia-a-dia - então o papel de Deus como causa e sentido da nossa existência ficou definitivamente relegado a segundo plano (LOYOLA, 2004, p. 1). 
E mais adiante, o autor conclui:

Num tempo em que nada se respondia sobre nossas origens, a idéia de Deus não era apenas aceitável, mas imprescindível. Hoje, quase to dos os passos do pó ao homem já foram compreendidos, ou pelo menos vislumbrados em um quadro geral completamente lógico e materialista. O Ateísmo, pela primeira vez na história da compreensão humana, recebeu o seu merecido lugar entre as autênticas formas de sabedoria (LOYOLA, 2004, p. 1).

Capra descreve de maneira elaborada como a mecânica newtoniana estendeu-se muito além dos corpos macroscópicos, avançando como a teoria definitiva dos fenômenos naturais, bem como os necessários avanços no campo da física a partir dessa concepção da natureza. No século XVIII, aponta 0 Iluminismo que propagava a teoria newtoniana do universo bem como a crença na abordagem racional dos problemas humanos. Locke, cujas idéias tornaramse a base para o sistema de valores do iluminismo e influenciaram o desenvolvimento do moderno pensamento econômico e político.

Os pressupostos da modernidade, a secularização, a ciência como única forma de explicar a realidade e a concepção do Estado como laico são assumidos pelo Grupo do Não. O pensamento de Capra reflete principalmente a questão da secularização e do cientificismo.

Quando distingue a ciência medieval da ciência contemporânea a partir da relação entre razão e fé, afirma que enquanto a primeira ocupava-se do significado, a segunda pretende ocupar-se com a predição e o controle. Exatamente na relação razão e fé reside uma das grandes questões do Grupo do Não.

Capra descreve como o homem deixa de ser a figura central da criação de Deus e, posteriormente, como este se afasta de Deus. O Grupo do Não entende que uma vez tendo explicações racionais para os fatos, o homem não precisa mais esconder-se atrás da idéia de um Deus.

Finalmente, ao tratar do iluminismo, fala da abordagem racional dos problemas humanos e da conseqüente compreensão de que as leis da natureza que governam a sociedade humana sejam semelhantes às que governam 0 universo físico. Tais concepções são claramente refletidas pelo Grupo do Não que não entende o homem como portador de uma dimensão religiosa e, conseqüentemente, não admite a transcendência.

A seguir, para melhor compreendermos o posicionamento do Grupo do Não, buscamos descrever a modernidade e a secularização.

Alain Touraine, no livro Crítica à Modernidade, no capítulo As luzes da razão, descreve a modernidade a partir de Locke e seus sucessores no pensamento filosófico. Assim descreve a secularização: 
(...) A secularização e o desencanto de que nos fala Weber, que definiu a modernidade pela intelectualização, manifesta a ruptura necessária com 0 finalismo do espírito religioso que exige sempre um fim da história, realização completa do projeto divino ou desaparecimento de uma humanidade pervertida e infiel à sua missão. A idéia da modemidade não exclui a de fim da história, como testemunham os grandes pensadores do historicismo, Comte, Hegel e Marx, mas o fim da histónia é mais o de uma pré-história e o início de um desenvolvimento produzido pelo progresso técnico, a liberação das necessidades e o triunfo do Espírito (TOURAINE, 1994, p. 17).

O autor faz a leitura exatamente do processo em que a modernidade substitui Deus pela ciência, deixando as crenças religiosas para a vida privada. Afirma que a modernidade às vezes imaginou a sociedade como uma ordem, uma arquitetura, outras fez da razão um instrumento para o interesse e 0 prazer dos indivíduos ou a utilizou contra todos os poderes para libertar uma "natureza humana" e conclui: "Em todos os casos, porém, ela fez da racionalização o único princípio de organização da vida pessoal e coletiva, associando-a ao tema da secularização, isto é, do desvinculamento de toda a definição dos 'fins últimos'" (TOURAINE, 1994, p. 18).

Em sua leitura, a mais forte concepção ocidental da modernidade é aquela que afirma que a racionalização exige a destruição dos laços sociais, dos sentimentos, dos costumes e das crenças chamadas tradicionais e de que o agente da transformação seja justamente a razão; esta, além de ser um componente indispensável da modernidade, se torna um mecanismo espontâneo e necessário de modernização. Merece destaque ainda a menção do autor de que essa idéia de sociedade moderna não corresponde à experiência histórica real dos países europeus, nos quais, segundo o autor: "(...) os movimentos religiosos e a glória do rei, a defesa da família e o espírito de conquista, a especulação financeira e a crítica social desempenharam um papel tão importante quanto os avanços técnicos e a difusão dos conhecimentos (...) (TOURAINE, 1994, p. 19).

Na seqüência afirma que essa idéia de sociedade moderna baseada na racionalização constituiu-se num modelo de modernização, numa ideologia, cujos efeitos teóricos e práticos, segundo o autor, foram consideráveis.

Afirma que a ideologia ocidental da modemidade substituiu a idéia de Sujeito e de Deus, à qual ela se prendia. A sociedade, a história e a vida individual deixam de estar submetidas à vontade de um ser supremo. 0 indivíduo está submetido às leis naturais. No que tange à educação, o autor assim se coloca:

O que vale para a sociedade, vale para o indivíduo. Sua educação deve ser uma disciplina que o liberte da visão estreita, irracional, que lhe impõem sua família e suas próprias paixões, e o abra ao conhecimento racional e à 
participação em uma sociedade que a ação da razão organiza. A escola deve ser um lugar de ruptura com o meio de origem e de abertura ao progresso, ao mesmo tempo pelo conhecimento e pela participação em uma sociedade fundada sobre princípios racionais. $\mathrm{O}$ professor não é um educador que intervém na vida privada das crianças que não devem ser outra coisa a não ser alunos; ele é mediador entre eles e os valores universais da verdade, do bem e do belo. A escola deve também substituir os privilegiados, herdeiros de um passado rejeitado, poruma elite recrutada através de provas impessoais realizadas através de concursos (TOURAINE, 1994, p. 20).

Voltaremos a essas concepções que, a nosso ver, fundamentam 0 Grupo do Não, uma vez que separam, por assim dizer, os campos de ação e atuação pública e privada, instituindo ainda a supremacia da razão e o distanciamento de tudo o que seja irracional.

Atribui a Locke a formulação mais clara da concepção do ser humano, descrevendo o homem como o conjunto de alma e corpo na experiência de sua identidade. 0 entendimento não dá forma às coisas, ele é reflexão, a qual repousa sobre uma sensação, e Locke insiste na sua passividade. Conclui que assim se define um pensamento sem garantia transcendente, desligado de Deus (TOURAINE, 1994, p. 21-22).

Sua descrição da modernidade que, segundo ele, substitui Deus pela ciência, é de que ela tem como pressupostos a compreensão da sociedade como ordem e da razão como instrumento para interesses e para libertar a "natureza humana". O Grupo do Não defende, como já o dissemos, a ciência em detrimento à idéia de Deus e vê a razão como instrumento de libertação daquilo que seriam as trevas impostas pela fé.

Assim como descrito por Touraine, o Grupo do Não defende a racionalização que passa pela destruição dos laços sociais, dos sentimentos, dos costumes e das crenças, visto que estes se constituem em obstáculos para a razão. É neste sentido que o ER, uma vez imposto à rede pública de educação, deve restringir-se ao estudo da história das religiões, desta forma estaria dentro de uma perspectiva racionalista e isento do risco de adentrar no mundo subjetivo das religiões.

Outro apontamento do autor muito presente para o Grupo do Não é o de que o indivíduo não está submetido à vontade de um ser supremo e sim às leis naturais. Importante para que o homem supere a si mesmo e seja construtor de sua história é a compreensão do espaço público e do privado e esta distinção é também apresentada pelo autor, ao descrever a modernidade, ao falar especificamente da educação compreendendo-a, bem como à escola, como responsáveis por levar ao conhecimento racional.

Nesta perspectiva cabe ao professor manter-se afastado da vida privada dos alunos, mantendo estrita relação com o conhecimento e não com as 
experiências de seus alunos. Visivelmente não cabe aqui uma proposta de um ER que busque a experiência do sentido ou que tenha como ponto de partida as experiências dos alunos ou ainda as diferentes experiências religiosas, como proposto pelo Fórum Nacional Permanente do Ensino Religioso.

Fica assim descrito por Touraine um pensamento, como ele mesmo o descreveu, sem garantia transcendente, desligado de Deus. O Grupo do Não reflete essas concepções ao demonstrar em seus textos os males impostos pela fé, pela reverência ao sagrado e às religiões, tanto aos indivíduos quanto aos grupos sociais.

Os conceitos de natureza e razão, afirma, têm como função principal unir o homem e o mundo, como fazia a idéia da criação. Esse apelo à natureza que tem a função de crítica anti-religiosa, procura dar ao bem e ao mal um fundamento social.

A formação de um novo pensamento político e social é o complemento indispensável da idéia clássica de modernidade, tal como está associada à de secularização. A sociedade substitui Deus como princípio do juízo moral e se toma muito mais do que um objeto de estudo, um princípio de explicação e de avaliação das condutas (TOURAINE, 1994, p. 24).

Para ele, a concepção da modernidade dos filósofos da Ilustração é revolucionária, porém significou apenas uma força na dissolução da antiga ordem sem, no entanto, construir uma nova. Para ele, a ideologia modernista não se ligou à idéia democrática, mas criticou em teoria e na prática o poder do rei e da Igreja católica em nome dos princípios universais e da própria razão.

As questões acerca da verdade na natureza e da razão tendo como função unir o homem e o mundo e, finalmente, a questão do poder da Igreja substituído pelo poder da razão são fundamentos da crítica de Touraine importantes para nos colocarmos posteriormente em relação ao Grupo do Não. Os dias recentes testemunham ainda 0 abismo em que se encontra o homem destituído do sentido de sua vida e ainda os lugares a que a humanidade chegou comandada pelo poder absoluto da razão bem como pelo poder $a b-$ soluto das religiões.

Trazemos neste momento uma leitura de Luckesi em seu livro Filosofia da Educação. Poderemos ver que sua proposição coincide com a visão de educação e escola do Grupo do Não. Mencionaremos ainda o pensamento de Anísio Teixeira.

Ao tratar de filosofia e educação, Luckesi a descreve como um "quefazer" humano. A educação dentro de uma sociedade se manifesta como um instrumento de manutenção ou transformação social. A reflexão filosófica sobre a educação dentro de uma dada sociedade é que deveria fornecer os 
referenciais para o estabelecimento de seus fins.

Também sobre a finalidade da educação, Anísio Teixeira assim se coloca ao falar dos padrões brasileiros de educação (escolar) e cultura:

A melhor compreensão, hoje, do fenômeno social de educação nos leva a conceituar as instituições educativas como instrumentos da transmissão da cultura, sua consolidação e sua renovação. Estudar, pois, a educação corresponde realmente a verificar em que grau a cultura de um povo está sendo mantida e nutrida para sua integração e renovação, como fenômeno histórico, dinâmico (TEIXEIRA, 1956).

Ao apresentar a tendência progressista "crítico-social dos conteúdos", afirma ser a difusão de conteúdos a tarefa primordial da escola. Para ele a valorização da escola como instrumento de apropriação do saber é o melhor serviço que se presta aos interesses populares (LUCKESI, 1994, p. 69).

Para o autor, a pedagogia "dos conteúdos", ao admitir um conhecimento relativamente autônomo, assume o saber como tendo um conteúdo objetivo, mas introduz a possibilidade de reavaliar este conteúdo, desta forma, professor e aluno podem ultrapassar a experiência, os estereótipos e as pressões difusas da ideologia dominante. Assim se pode ir do saber ao engajamento político.

A seguinte afirmação abre precedentes para a reflexão que fazíamos anteriormente, ao apontar para a realidade social e para a experiência do aluno:

(...) Há um confronto do aluno entre sua cultura e a herança cultural da humanidade, entre seu modo de viver e os modelos sociais desejáveis para um projeto novo de sociedade. E há um professor que intervém, não para se opor aos desejos e necessidades ou à liberdade e autonomia do aluno, mas para ajudá-lo a ultrapassar suas necessidades e criar outras, para ganhar autonomia, para ajudá-lo no seu esforço de distinguira verdade e o erro, para ajudá-lo a compreender as realidades sociais e a sua própria existência (LUCKESI, 1994, 74).

Sobre o papel da escola, Anísio Teixeira assim se coloca:

A escola, portanto, não surge como instituição destinada a substituir a influência direta da sociedade, nas suas formas de participação educativa, pela vida de família, pelo trabalho em comum, ritos comuns e recreação em comum; mas, sim, como uma instituição específica para a formação de especialistas da tradição escrita, a latere, e sem prejuízo daquela influência social direta, quanto à participação e integração de todos na comunidade (TEIXEIRA, 1956). 
Ao falar de uma perspectiva para a escola como instância de mediação pedagógica, Luckesi afirma que um dos objetivos fundamentais da ação pedagógica é a transmissão e assimilação do legado cultural da humanidade, o primeiro núcleo da atuação da escola. O segundo é a formação da personalidade do educando, a transmissão do legado cultural, sua apropriação e crítica contribuirão para que o educando adquira uma maneira de ser, uma personalidade. O terceiro núcleo é o mundo afetivo da criança, do adolescente, do jovem. O objetivo principal da escola é a transmissão e assimilação ativa dos conhecimentos, mas ela não pode descurar, para utilizar a palavra do autor, dos aspectos afetivos do educando.

Ao descrever os sujeitos da práxis pedagógica, apresenta sua visão de homem:

Podemos concluir, sinteticamente, que o ser humano manifesta-se (1) ativo (ele trabalha e modifica o ambiente para atender as suas necessidades; (2) construído por sua atividade (enquanto age, se auto-constrói); (3) dentro das relações sociais determinadas (condicionantes que atuam sobre ele); e (4) como construtor da própria sociedade (utilizando-se das condições desta) (LUCKESI, 1994, p.114).

Quanto ao conhecimento, o descreve, em síntese, uma forma de entendimento da realidade.

Na leitura destes autores percebemos a caracterização da educação e da escola coerentes com o Grupo do Não, uma vez que dão ênfase à escola crítica, comprometida com o social e desvencilhada das chamadas questões de interesse privado, como a religião, por exemplo.

\section{Considerações finais}

Neste artigo tratamos do Grupo do Não e entendemos que contribuímos ao apresentar de maneira sistematizada o posicionamento deste grupo. Apontamos que a questão fé e ciência na Internet pode ser fonte de novos estudos.

Quando tratamos dos fundamentos deste grupo, reconhecemos o quanto vasta é a bibliografia a respeito. Importa destacar que nosso objetivo era indicar os fundamentos de modo a contribuir para uma epistemologia do ER.

Salientamos que a leitura de Capra e Touraine foi importante para que pudéssemos entender tais fundamentos, embora eles sejam críticos em relação à modernidade e suas conseqüências. 
Entendemos como relevante este estudo para a compreensão da problemática do ER, visto considerarmos que estão na esfera epistemológica as confusões, as reduções e as indistinções.

Nosso objetivo, para além do levantamento das fontes e seus fundamentos, compará-las e analisar seu reflexo nos textos legais, é preparar o caminho para que, posteriormente, possamos tratar essencialmente do pedagógico do ER: sua especificidade, uma didática e um currículo que lhe sejam próprios.

Ao ER não caberá buscar a adesão do aluno a uma confissão de fé. Concordamos que esta não seja uma atribuição de uma disciplina pertencente a um currículo escolar, mas que tenha algo a dizer sobre um conhecimento que pode em muito contribuir para a visão de mundo do educando, com a qual entendemos que caiba à educação em geral e à escola, de maneira específica, contribuir.

Mas somente contribuir com o conhecimento não basta, como não deveria bastar a nenhuma disciplina, torna-se necessário e urgente, a nosso ver, comprometer-se em auxiliar nossos educandos na busca do sentido de sua vida. A compreensão de uma educação transformadora também faz parte dessa busca.

A pergunta que faço é: o conteúdo religioso e a busca pelo sentido da vida estariam, necessariamente, fora das realidades sociais e da experiência de nossos alunos?

Não caberia ao ER, compreendido como área do conhecimento, auxiliar o homem e a mulher modernos em sua busca pelo ser mais, por meio de uma melhor compreensão de si mesmos e de sua relação com a natureza, com os outros e com o Transcendente? Não seria possível ao ER não buscar a adesão à prática de fé nem mesmo desconsiderar os que não têm fé e simplesmente buscar uma reflexão apurada acerca das experiências, dos fatos religiosos?

Querendo ou não, uma coisa é certa, pouco podemos falar do mundo moderno sem que tenhamos de fazer referência a fatos religiosos ou a condutas de crentes e de não-crentes, inspiradas pelo fato de crerem ou não crerem!

Merece reparo o trato dado ao ER na escola pública e na escola católica. Em muitos momentos, quer na prática, quer no discurso, parece haver uma tendência da CNBB a considerar que o ER na escola católica deva ter um perfil diferenciado do ER na escola pública. Na busca por uma epistemologia do ER não importa, num primeiro momento, justificar ou não a validade desta diferenciação; mas é necessário destacar que, no bojo desta discussão, está evidente a falta de clareza quanto à compreensão do ER como disciplina. Afinal, não cogitamos as possíveis diferenças a serem estabelecidas no ensino 
da matemática ou da língua portuguesa no ambiente laico da escola pública ou católico da escola particular.

Parece-nos que o objeto do ER poderia ser o fenômeno religioso; as Tradições Religiosas, nas proposições temáticas do próprio Fórum e a questão do sentido da vida que trataria da essência das religiões, do sagrado, daquilo que, em todas elas, seja gerador de vida e não apenas do como e quanto estas religiões, por seus aspectos institucionais, influem na cultura. Sim, porque é verdadeiro afirmar que as influências de maior impacto no seio das culturas e das sociedades sejam das instituições religiosas e não simplesmente do fato religioso.

Em relação às concepções do Grupo do Não, o que podemos salientar é a dificuldade na compreensão do ER como disciplina em função de uma questão prática: o embasamento em discursos contraditórios dos representantes oficiais da Conferência Nacional dos Bispos do Brasil, os quais evidenciaram as contradições em função do desconhecimento da caracterização do ER como disciplina. O próprio fato de os Parâmetros Nacionais do Ensino Religioso não terem sido reconhecidos pelo Ministério da Educação e Cultura faz com que ganhe força o discurso oficial da Igreja católica que, é preciso destacar, discute há mais tempo a questão e, sem sombra de dúvida, exerce maior influência no contexto da sociedade brasileira. Ao mesmo tempo, aprová-lo ou não se constitui num verdadeiro desafio já que são tão oponentes os campos de força, marcadamente a CNBB e o Grupo do Não.

Neste momento, cabe-nos, a título de esclarecimento, lembrar que no que tange ao Grupo do Não, objetivamos mostrar como a busca do conhecimento científico e suas postulações fundamentam esse grupo na medida em que se distancia do, por assim dizer, mundo religioso. Porém, ao descrever o caminho do pensamento científico, a partir da leitura de Fritjof Capra, cumprenos destacar que essa leitura mostra uma evolução gradual e, conseqüentemente, não abandona os pressupostos medievais da leitura religiosa de uma hora para outra. Respeitamos esse processo histórico e biográfico, ainda que nosso autor, Capra, vá evoluir em seu livro para demonstrar a inconsistência e as respectivas perdas do afastamento humano de suas crenças.

Entendemos como necessário esse respeito a uma leitura processual da realidade e mesmo das questões relativas ao ER na escola. Há uma caminhada, sem dúvida alguma portadora das maiores fragilidades, mas há de se reconhecer também os elementos positivos dessa caminhada rumo a um ER que se constrói na prática cotidiana e, aparentemente a despeito de todos os que sobre ele se posicionam, este ensino se faz no dia-a-dia da sala de aula e a partir dos anseios de seus maiores interlocutores: os educandos.

Salientamos a importância de atentarmos para o discurso do Grupo do Não como um contraponto necessário para que possamos refletir critica- 
mente sobre essa disciplina e buscarmos a correção de tudo aquilo que possa inviabilizar o trato pedagógico do ER. Desta forma, podemos afirmar, respondendo à questão-título deste artigo, que haverá sim um lugar na escola para 0 Ensino Religioso!

\section{Referências}

CANDIA, Antônio Carlos. Sociedade da terra redonda: educação religiosa e ensino público. Disponível em: 〈http://www.strbrasil.com.br>. Acesso em: 05 set. 2002.

CÂNDIDO, Viviane Cristina. O ensino religioso em suas fontes: uma contribuição para a epistemologia do ER, 2004. Dissertação (Mestrado em Educação) - Centro Universitário Nove de Julho. São Paulo, SP: 2004.

CAPRA, Fritjof. O ponto de mutação: a ciência, a sociedade e a cultura emergente. 24. ed. São Paulo, SP: Cultrix, 2003.

CARON, Lurdes. (Org.). O ensino religioso na nova LDB: histórico, exigências, documentário. Petrópolis, RJ: Vozes, 1997.

DURANT, Will. A história da filosofia. Tradução de Luiz C. do N. Silva. São Paulo, SP: Nova Cultural, 1991. Título Original: The story of Phylosophy.

ECO, Umberto; MARTINI, Carlo Maria. Em que crêem os que não crêem? 4. ed. Tradução de Eliana Aguiar. Rio de Janeiro, RJ: Record, 2000. p. 160.

FIGUEIREDO, Anísia de Paulo. Ensino religioso: perspectivas pedagógicas. Petrópolis, RJ: Vozes, 1994.

. O ensino religioso no Brasil: tendências, conquistas, perspectivas. Petrópolis, RJ: Vozes, 1995.

FORUM NACIONAL PERMANENTE DO ENSINO RELIGIOSO. Parâmetros curriculares nacionais: ensino religioso. 2. ed. São Paulo, SP: Ave Maria, 1997.

GONÇALVES FILHO, Tarcizo. Ensino religioso e a formação do ser político: uma proposta para a consciência de cidadania. Petrópolis, RJ: Vozes, 1998.

GRUEN, Wolfgang. O ensino religioso na escola. Petrópolis, RJ: Vozes, 1995.

INOUE, Ana Amélia; MIGLIORI, Regina de Fátima; D’AMBROSIO, Ubiratan. Temas transversais e educação em valores humanos. São Paulo, SP: Petrópolis, 1999. 
KÜNG, Hans. Projeto de ética mundial: uma moral ecumênica em vista da sobrevivência humana. Tradução de Haroldo Reimer. São Paulo, SP: Paulinas, 1993.

LOYOLA, Rodrigo. Sobre a ciência, o ateísmo e outras formas de sabedoria. Disponível em: <http://www.icb.ufmg.br/ franc/cool/ciencia/ crencas.html>. Acesso em: 31 jan. 2004.

LUCKESI, Cipriano Carlos. Filosofia da educação. São Paulo, SP: Cortez, 1994.

PADEN, William E. Interpretando o sagrado: modos de conceber a religião. São Paulo, SP: Paulinas, 2001.

QUEIROZ, José J. (org.). Ética no mundo de hoje. São Paulo, SP: Paulinas, 1985.

SCHWARTSMAN, Hélio. Sociedade da terra redonda: 0 parlamentar que votou contra Deus. Disponível em: <http://www.strbrasil.com.br >. Acesso em: 05 set 2002.

SECRETARIADO PARA OS NÃO-CRISTÃOS. A igreja e as outras religiões: diálogo e missão - documentos da igreja católica. 2. ed. São Paulo, SP: Paulinas, 2002.

SOTTOMAIOR, Daniel. Sociedade da terra redonda: ensino religioso nas escolas. Qual Deus?Disponível em: <http:// www.strbrasil.com.br>. Acesso em: 05 set 2002.

TEIXEIRA, Anísio. A educação e a crise brasileira. São Paulo, SP: Cia. Editora Nacional, 1956.

TOURAINE, Alain. Crítica da modernidade. Petrópolis, RJ: Vozes, 1994.

VALDEJÃO, Renata de Gáspari. Religião será facultativa para os alunos. Folha de São Paulo, São Paulo, SP: 18 ago. 2001. p. C5.

VIESSER, Lizete Carmem. Um paradigma didático para o ensino religioso. Petrópolis, RJ: Vozes, 1994. 